\title{
Perceptions of Syrian Student Refugees towards Blended Learning: Implications for Higher Education Institutions
}

\author{
https://doi.org/10.3991/ijet.v15i01.11431 \\ Naima Ahmad Al-Husban $\left.{ }^{(}\right)$, Sameera Mahmoud Alshorman \\ Arab Open University Jordan, Jordan, Amman \\ naimahusban@yahoo.com
}

\begin{abstract}
This study investigates the Syrian refugees' perceptions of blended learning (BL) at Arab Open University in Jordan as well as the effects of age and gender on participants' perceptions. A questionnaire was used to collect data from 93 Syrian refugees. Results revealed that the Syrian refugees have positive perceptions of the BL approach, and they are satisfied with it as it plays a transformative role in achieving their academic goals without negatively affecting their work and family affairs. Results also revealed there were no significant differences in participants' perceptions of BL attributed to gender, but age had a significance differences, that is, older participants view BL favorably. The current study also investigated the challenges that refugees face when experiencing $\mathrm{BL}$. Based on the results, it is recommended to expand the use of $\mathrm{BL}$ approaches, especially for vulnerable groups like refugees while taking into consideration the challenges they stated. Further research should be conducted to investigate other variables that affect participants' perceptions like achievement, and majors.
\end{abstract}

Keywords - Blended learning, Syrian Refugees, perceptions

\section{Introduction}

Blended learning, which integrates face- to -face tutorials and online learning, is today considered a mainstream approach to learning in higher educational institutions, as well as international agencies that are concerned with tertiary education, such as UNESCO and UNHCR. For example, [1] called all states to provide quality education and lifelong learning for every one across all modes, including using technology, online learning, and blended learning. Similarly, the Organization of Economic Cooperation and Development (OECD, 2016) and the European Commission (2017) emphasized the need for quality and different education that takes into consideration the challenges of future and the global demands.

Wars and crises, and their effects on people in such countries like Syria could be a prominent example of these demands. During the last eight years, about 1.3 million Syrian refugees, 120.000 young Syrian refugees are waiting for having a chance to enroll in higher education, as tertiary education for this vulnerable group is considered 
to be an instrument of protecting the refugees, and change them to agent of encountering terrorism [2].

However, several barriers prevent Syrians from continuing their tertiary education, such as, the university regulations, financial reasons, and their family or work circumstances, and accreditation. Therefore, the host communities like Jordan and others should think of tertiary education models that meet the demands and circumstances of this vulnerable group. According to [3], blended learning is an innovative approach to provide refugees with tertiary education that helps them to be active citizens in the host community and in their homeland in the post-war period. It is known that people' perceptions of something are of paramount importance because they can lead to the success of that thing, so it is necessary to investigate the perceptions of Syrian students on enrolling in tertiary education in the form of blended learning.

Arab Open University - Jordan plays a leading role in employing blended learning not only in Jordan but also in the Middle East. The researchers found that studying the perceptions of refugees who were enrolled at Arab Open University- Jordan since 2015 could answer this question, and provide evidence and important results for policy makers and international agencies that may want to fund projects related to blended learning.

\section{Theoretical Background}

"Ensuring inclusive and equitable quality education and promoting lifelong learning opportunities for all" are among the main pillars of the 2030 agenda for sustainable development. One of the challenges for the international community is to provide this right to refugees, particularly in the Middle East. The Syrian crisis could be one of the greatest crises. It generated millions of refugees, especially young refugees who are willing to enroll at higher education institutions; many of them left their homeland during their studies at university and did not continue their studies there.

Jordan is one of the countries most affected by the Syrian crisis, with the second highest share of refugees compared to its population in the world, 89 refugees per 1000 inhabitants. According to the Ministry of Planning (MOP), Jordan is hosting about 1.3 million Syrians [3].

Due to the financial constraints on Jordan, the attempts of the Jordanian authority to accommodate for the influx of Syrian refugees students to the higher education sector were limited. Additionally, many stakeholders including international organizations, provided scholarships for a limited number of Syrian refugees to continue their studies at the university level just after 2015 of the crisis, but most of them lost the scholarships due to their personal conditions. Most young refugees either work and study at the same time or the female refugees have children and cannot leave their families every day. If the achievements of the grantees were not sufficient and the grantees did not attend most lectures, they would lose the scholarship.

This situation unfortunately poses a huge threat to the financial status and quality of life of the refugees. Furthermore, uneducated generations will not be equipped to rebuild the economic, educational, and infrastructure sectors in post-war Syria. There- 
fore, this leads to the fact that Syrian refugees need a tertiary education that takes into consideration their challenging circumstances.

Particular attention should be paid to the tertiary education for refugee students, as it is significant for the future of Syria as well as the host community. In this context, research supports the need to include tertiary education in the global movement for the provision of education to refugees, especially because it is a tool of protection, it offers the opportunities to be peace builders, and it can serve as a counter-terrorism method [2]. However, to meet the needs of Syrian refugees, traditional tertiary education is not the best choice, according to [4], they recommended that it is necessary to go beyond on-campus offerings, providing other models of tertiary education.

This could be achieved by introducing dynamic pedagogical practices in which the focus should be on the students rather than the tutors, through using active, interactive, and experiential models that develop their competencies and support their personal conditions as workers or mothers; blended learning could be one of these models for Syrians in tertiary education. Similarly, [5] stated that providing blended learning as an innovative approach for tertiary education for the refugees has promising outcomes, as it provides flexibility and accessibility, and it is a chance to develop the educational skills and abilities of the refugees. Additionally, as it is stated in its report, great demand and interest in blended learning opportunities by the refugees community in Jordan is anticipated.

\subsection{Blended learning}

Blended learning approach is an innovative approach to learning that combines the strengths of e-learning with some of the positive aspects of the traditional ways of teaching at the university level, such as face-to-face interaction; in other words, blended learning integrates traditional lecturing with virtual learning together in a blended way [6]. [7] stated that blended learning has several names, such as, mixed mode instruction, and hybrid learning. It was employed for the first time in 1999 during the introduction of the foundation called interactive learning center. In turn, [8] classified the years from 1999 to 2002 as the first attempt time of blended learning, and the years between 2003 to 2006 as its definition period and the years between 2007 to 2009 as the time of its reputation.

Blended learning is one of the recent approaches that is recommended by many researchers [24] because it has several benefits for students. For example, [7], [9] clarified that most efforts focused on encouraging students to use blended learning, especially in higher education, as it meets the students' needs, such as satisfaction of learning, enhancing convenience and learning chances, offering effective learning experiences that focus on students and tutors with each other communicating and collaborating, facilitating students' access to resources, and giving students feedback online and face-to-face. These strengths made policy makers and decision makers, and researchers to think of blended learning and its potential as a prominent model of learning now and in the future.

This tendency could be due to the bases that this approach relies on: the principles of constructivism, by taking the effective point of traditional learning "face- to-face 
interaction" and combining it with some attributes of online learning to help students become more engaged and make their learning more meaningful. Furthermore, social constructivism could be used in blended learning by working in teams, and in collaborative way, and the instructors have a great role in guiding students online and faceto-face in how to make meaning and construct their own knowledge [10], [24].

These characteristics make researchers very interested in identifying the effects of this approach on several variables, such as students' achievement, and they found it improves students' achievement over other approaches like traditional or on-line learning such as [11]. Researchers have also investigated the effect of blended learning like instructors' opinions, perceptions, attitudes towards blended learning on other areas, like instructors' opinions, perceptions, and attitudes towards blended learning [10], [12], [13], [22], [23]. They found that students and instructors valued aspects of blended learning and had a positive perception of it, but students need more capacity building in how to employ it effectively.

The great interest in using blended learning in Jordan is similar to most countries, and many universities started teaching some courses using the attributes of blended learning. However, Arab Open University has achieved a lot in the field of blended learning by providing online services such as the learning management system (LMS), which provides tutors and students with discussion forums where they can participate by writing and interacting with tutors and their peers. This capability is especially important to the students at Arab Open University who do not have time for doing homework, as most of them work or have other responsibilities, and the face to face lectures are limited to once a week. Therefore, this system is very suitable for them as a means of developing their educational background and deepening their critical thinking, especially if the discussion forums are structured strategically and meaningfully.

Some studies have been conducted recently in the Jordanian context focusing on some case studies of blended learning to measure its effect on the students' achievements. Results revealed that participants who studied using blended learning outperformed those who studies o0nly in a traditional way. Result also showed no effects of the variables of gender and age in determining the perceptions of participants [13], [14], [15], [16]. It can be concluded the research area about blended learning emphasized on students' performance were the prominent research areas about blended learning emphasized students' performance, whereas no study investigated students ' perceptions of the components of blended learning, particularly refugee students at the university level.

Their perceptions were not investigated in spite of the international calls for providing refugees students with blended learning as it provides them the quality of learning without staying at university for a long time, and is one of the essential requirements of traditional higher education according to international agencies like UNESCO and UNHCR

Some studies at the international level examined the students' perception of blended learning, for example, [7], [12], [17], [18]. They found that students who experienced blended learning had positive perceptions of blended learning, and they were satisfied with the convenience, ease of use of online services, flexibility of learning, 
and smart lectures. These studies reveals that the success of blended learning is greatly dependent on students' perception.

Similarly, [19] conducted a study about the perceptions of university students in the middle East particularly I the United Arab Emirates (UAE); results revealed that the participants of the study had positive perceptions of blended learning, and how it leads to female empowerment. Moreover, [22] found that resource - challenges communities motivate the use of blended learning in its limited learning environment because blended learning has the potential of having quality learning at any time and in anywhere.

This reveals the importance of investigating the perceptions of students refugees as most funding agencies tend to support projects based on providing refugees with tertiary education using blended learning in the light of its stakeholders' reports. For example, HOPES project reported some conclusions during its conference in 2017, saying that discussions proved that refugees especially Syrians in the Middle East are increasingly open-minded towards blended learning, and appreciate it if they have access to the necessary technical equipment.

Having the official recognition of certificates, and blended learning is their best alternative as it takes into consideration their hard circumstances. Therefore, it could be concluded that it is of paramount importance to investigate refugees students' perceptions of blended learning to provide policy makers in higher education, international agencies, and researchers research-based data about the effectiveness of this approach for people who lived in hardship and suffering from various financial and social problems, especially [5] conducted a study about innovative education approach- connected $\backslash$ blended learning for refugees. The sample was 26 persons $85 \%$ of them were Syrian students at universities. It was found that $54 \%$ of the participants in the study were familiar with blended learning, but $46 \%$ of them did not have any idea about the term.

Therefore, this finding reveals the importance of conducting further research about this issue to understand refugees' perceptions of all the components of blended learning by investigating the perceptions of more Syrian refugees. Many Syrian refugees enrolled in Arab Open University-Jordan since 2015 after the Syrian crisis, and at the same time, Arab Open University is applying blended learning systems in all its branches and Jordan is one of them, it is essentially involves applications of elearning, techniques along with face to face tutorials [20]. This environment could provide accurate picture about the refugees students' perceptions about blended learning becuase they experienced it thoroughly. Therefore, this study aimed to reveal how the blended learning was perceived by the Syrian refugees' students.

\section{Research Objectives, Questions, and Definition of Terms}

Blended learning has recently become an innovative approach in higher education especially for refugees' students, due to its flexibility and convenience in dealing with studies. However, its impact on students and their performance, engagement, and perception is still a topic of debate, particularly for refugees. Moreover, there is lim- 
ited research in the area of perceptions of refugees of blended learning internationally and in the Middle East region. This study is an attempt to fill the existing gap. Within the scope of this research, answers to the following questions were sought:

- What are the reasons for selecting blended learning systems at the higher education stage?

- What are the Syrian refugee students' perception on blended learning at Arab Open University (AOU)?

- Are there any significant differences among Syrian refugees attributed to their gender?

- Are there any significant differences among Syrian refugees attributed to their age?

- What are the challenges you face while studying in blended learning system?

\section{Definition of terms}

- Perceptions: The point of view of the participants towards blended learning, and how they interpret and organize the sensory information about blended learning.

- Blended learning: It is an eclectic model designed to lessen the negative aspects of online and face-to-face learning and the convergence of the advantages of both approaches.

\section{$4 \quad$ Methodology}

The aim of the current study was to investigate refugee students' perceptions of blended learning implemented at Arab Open University, and if there were significant differences attributed to gender or their age. Accordingly, a descriptive quantitative method was followed for the purpose of a study that relied on a printed questionnaire for data collection. A questionnaire as a research tool provides benefits related to standardized responses to a specific topic from a large sample or population. It is cheap, reliable, valid, and easy to complete; it is also widely used, and a useful instrument for collecting survey information, and providing structured and numerical data [21].

The items of the questionnaire were built according to the review of the related literature as well as the context of conducting the study. It consisted of two main sections: demographic information (gender, age, and the device they use in blended learning), and refugees students' perception of blended learning. In building the questionnaire, a Likert's 3-point scale was established from $3=$ agree in a high level to $1=$ disagree for positive items and reverse order for negative items. The items of the questionnaire were followed by open- ended questions to asking students about their opinion of continuing their higher education using blended learning, and the challenges they faced. 


\subsection{Validity and reliability of the research tool}

To ensure the validity of the instrument, the questionnaire was submitted to a jury of four specialists in educational technology, and two experts majoring in measurement and assessment. Most of their comments focused on rewording or clarifying some items. All of their comments were taken into consideration in the final version of the instrument.

To measure the reliability of the research tool, the researcher conducted a pilot study that used the Cronbach alpha coefficient. The research tool consisted of 33 items, the Cronbach alpha coefficient was 0.866 , and this reveals that the internal consistency of the research tool was considered appropriate for the purposes of this study. The questionnaire reliability was also verified through the test- retest method on a pilot study that consisted of 14 refugees' students. The time was between the two tests was two weeks, and the results were calculated using Pearsons' correlation coefficient between the two tests. The result was 0.874 , and it is appropriate for the purpose of the study.

The online questionnaire was sent to 282 Syrian refugees who study at Arab Open University-Jordan. 93 Syrian students responded to it; it is about (33\%) of the whole population.

\subsection{The sample of the study}

The current study targeted all the Syrian refugees enrolled at the Arab Open University-Jordan after the Syrian crisis; they are about (282 Syrian refugees). The sample was (93) Syrian refugees, (50) females, and (43) males. The questionnaire was sent online using the Learning Management System (LMS) of the university during the academic year 2018/2019: participants were in their first or second year of study at Arab Open University.

The participants were provided with a thorough explanation of the main purpose of the study during the lectures, and they were asked to participate voluntarily after getting their approval to participate. They were also informed that the data was confidential and would be used for the research purposes, and they could withdraw from completing the questionnaire items at any time.

Data was then sorted, and reviewed, and analysis was conducted using the Statistical Package for Social Sciences (SPSS) software. Descriptive statistics included frequencies, percentages, means, and standard deviations, and a T- test for independent samples was used to answer the research questions.

\section{$5 \quad$ Results}

93 out of 282 Syrian refugees' students completed the online questionnaires; 50 $(53.7 \%)$ were female refugees, while $43(46.3 \%)$ were male refugees. The majority of the respondents (64\%) were between 18 and 29 , and $36 \%$ of them were more than 29 years old. The respondents were students in different departments as follow: $20 \%$ 
from the education department, $10 \%$ from the English department, $10 \%$ from information technology (IT), 15\% from graphic design, 15\% from business administration, $20 \%$ from press and media, and $10 \%$ from accounting department. Most respondents (67.2\%) used the services of the LMS of the university via their mobile phones and the university provided them online access at the university, and (32.8\%) of them used their laptops. Results of the questionnaire and the interview interestingly revealed that participants of the study became familiar with the LMS a few weeks after enrolling the university as the university held a demonstration workshop to familiarize them with the services that they could use to maximize benefits.

Question number 1: What are the reasons for selecting blended learning systems at the higher education stage?

Participants were given three options to describe their conditions and why they chose this system of study. Results are presented in Table 1:

Table 1. Reasons for selecting the blended learning system of studying at higher education

\begin{tabular}{|l|c|c|}
\hline \multicolumn{1}{|c|}{ Reasons of selecting blended learning system } & Frequencies & Percentage \\
\hline Limited times of going to the university site & 90 & $81.1 \%$ \\
\hline This system allows me to be committed to a job & 70 & $63.6 \%$ \\
\hline This system allows me to take care of my kids and family & 50 & $45.5 \%$ \\
\hline This system gives time and flexibility in studying. & 12 & $11 \%$ \\
\hline
\end{tabular}

Table 1 reveals that the participants found this system took into consideration their private conditions, so the majority of the participants selected this system due to the limited times of going to the university and because this system took into consideration their work and family conditions.

Question number 2: What are the Syrian refugee students' perceptions of blended learning at AOU?

To answer this question, the questionnaire items were divided into the following sections:

Table 2. Participants' perceptions of tutors' practices within blended learning

\begin{tabular}{|l|c|c|c|}
\hline \multicolumn{1}{|c|}{ Items } & $\begin{array}{c}\text { Agree to a high } \\
\text { level }\end{array}$ & $\begin{array}{c}\text { Agree to a } \\
\text { middle level }\end{array}$ & Disagree \\
\hline Tutors provided me with enough feedback & $56(60.2 \%)$ & $21(22.6 \%)$ & $16(17.2)$ \\
\hline Tutors employed asynchronous forums effectively & $47(50.5 \%)$ & $23(24.7 \%)$ & $23(24.7 \%)$ \\
\hline $\begin{array}{l}\text { PowerPoint presentations and the videos prepared by tutors } \\
\text { were helpful }\end{array}$ & $40(43 \%)$ & $29(31.2 \%)$ & $24(25.8)$ \\
\hline Tutors assessed me using several ways not only exams & $54(58.1 \%)$ & $22(23.7 \%)$ & $17(18.3 \%)$ \\
\hline I can communicate with tutors at any time using LMS & $41(44.1 \%)$ & $28(30.1 \%)$ & $24(25.8 \%)$ \\
\hline $\begin{array}{l}\text { Tutors replied directly to my inquiries regarding the } \\
\text { courses }\end{array}$ & $61(65.6 \%)$ & $16(17.2 \%)$ & $16(17.2 \%)$ \\
\hline $\begin{array}{l}\text { Tutors provided summary, suggested questions, and } \\
\text { additional reading so it enriched my knowledge of the } \\
\text { course }\end{array}$ & $41(44.1 \%)$ & $31(33.3 \%)$ & $21(22.6 \%)$ \\
\hline
\end{tabular}


Table 2 reveals that most respondents were satisfied with the tutors' practices within the blended learning system. Most respondents agreed to a high degree with the effectiveness of tutors' practices while studying in blended learning system. A majority of participants stated tutors provided enough feedback, employed asynchronous forums, and provided the necessary resources for students in advance. The students also stated that they could communicate with tutors and the tutors would reply to them.

Table 3. Students' perception of the advantages of studying within the blended learning system

\begin{tabular}{|l|c|c|c|}
\hline \multicolumn{1}{|c|}{ Items } & $\begin{array}{c}\text { Agree to a high } \\
\text { level }\end{array}$ & $\begin{array}{c}\text { Agree to a middle } \\
\text { level }\end{array}$ & Disagree \\
\hline Blended learning helps me to be a self -learner & $40(43 \%)$ & $29(31.2 \%)$ & $24(25.8 \%)$ \\
\hline $\begin{array}{l}\text { Blended learning improved my skills of using } \\
\text { computers and internet }\end{array}$ & $44(47.3 \%)$ & $27(29 \%)$ & $22(23.7 \%)$ \\
\hline Blended learning saves my time to do my other duties & $40(43 \%)$ & $29(31.2 \%)$ & $24(25.8 \%)$ \\
\hline This system is flexible to do my own work & $58(62.4 \%)$ & $35(37.6 \%)$ & $0(0 \%)$ \\
\hline $\begin{array}{l}\text { it is impossible to enroll at university without this } \\
\text { kind of system }\end{array}$ & $65(69.9 \%)$ & $20(21.5 \%)$ & $8(8.6 \%)$ \\
\hline $\begin{array}{l}\text { It is a good system as I do not have to pay } \\
\text { transportation expenses }\end{array}$ & $65(69.9 \%)$ & $20(21.5 \%)$ & $8(8.6 \%)$ \\
\hline $\begin{array}{l}\text { It helps me to follow up my studies via LMS when I } \\
\text { could not issue an entry permit from the camp }\end{array}$ & $72(77.4 \%)$ & $16(17.2 \%)$ & $5(5.3)$ \\
\hline
\end{tabular}

As shown in Table 3, from $43 \%$ to $77.4 \%$ of the respondents agreed that blended learning has several advantages over the traditional system of higher education institutions, and they recognized that several skills they have developed due to using this system in their studying. This system helped them to continue their higher education, as they do not have to go to the university sites every day, so they save money and time to do other tasks that could yield money. Therefore, they had positive perceptions of studying at the university with this system.

Question number 3: Are there any significant differences among Syrian refugees attributed to their gender?

The current study investigated Syrian refugee students' perceptions of blended learning and if their perceptions differ according to their gender. To answer this question the means and standard deviations of the males and females groups were used and a t- test of independent samples was used.

To check the effect of gender on Syrian refugees' perceptions, Table 4. below shows the means and the standard deviations of each group regarding their perceptions of blended learning.

Table 4. The mean and standard deviations of males and females of their perceptions of blended learning

\begin{tabular}{|l|c|c|c|c|}
\hline \multicolumn{1}{|c|}{ Gender } & N & Mean & Std. deviation & Std. error mean \\
\hline Males & 40 & 2.5605 & 0.42332 & 0.06693 \\
\cline { 2 - 5 } Females & 53 & 2.6100 & 0.37703 & 0.05179 \\
\hline
\end{tabular}


Table 4 shows that the mean of the males was (2.56) out of (3), with a standard deviation of (0.42332) and the mean of the female group was (2.61) out of (3), with a standard deviation of $(0.37703)$.

As can be noticed, the mean of the female group was apparently different and higher than that of the male group. To examine if the differences in means between males and females were statistically significant, a t-test for independent samples was calculated; the results are presented in Table (5)

Table 5. T-test for independent samples for the differences in perceptions of BL between males and females

\begin{tabular}{|c|c|c|c|c|c|c|c|c|}
\hline & \multicolumn{7}{|c|}{ t-test for Equality of Means } \\
\hline & & \multirow[b]{2}{*}{$T$} & \multirow[b]{2}{*}{$D f$} & \multirow{2}{*}{$\begin{array}{c}\text { Sig. } \\
(2- \\
\text { tailed })\end{array}$} & \multirow{2}{*}{$\begin{array}{c}\text { Mean } \\
\text { Difference }\end{array}$} & \multirow{2}{*}{$\begin{array}{l}\text { Std. Error } \\
\text { Difference }\end{array}$} & \multicolumn{2}{|c|}{$\begin{array}{c}\text { 95\% Confidence Interval } \\
\text { of the Difference }\end{array}$} \\
\hline & & & & & & & Lower & Upper \\
\hline \multirow[t]{2}{*}{ Average } & $\begin{array}{l}\text { Equal variances } \\
\text { assumed }\end{array}$ & 0.005 & 91 & 0.996 & 0.00044 & 0.08326 & -0.16495 & 0.16583 \\
\hline & $\begin{array}{l}\text { Equal variances } \\
\text { not assumed }\end{array}$ & 0.005 & 78.559 & 0.996 & 0.00044 & 0.08463 & $0-.16802$ & 0.16891 \\
\hline
\end{tabular}

Table 5 reveals that there were not statistically significant differences between the males and the females groups in their perceptions at $(\alpha=0.05)$, since the $(\mathrm{T})$ value was (005) without statistically significant level because the level of significance (0.996) is more than $(\alpha=0.05)$. This means there was no significant differences between males and females in their perceptions of blended learning.

Question number (4): Are there any significant differences among Syrian refugees attributed to their age?

To answer this question the means and standard deviations of the two groups of ages (less than 29 and more than 29) were used, and a t- test of independent samples was used.

To check the effect of age on Syrian refugees' perceptions. Table (6) below shows the means and the standard deviations of each group regarding their perceptions of blended learning.

Table 6. The mean and standards deviations of Syrian refugees' participants who are more than 29 and less than 29 in their perceptions of blended learning

\begin{tabular}{|c|l|c|c|c|c|}
\hline \multicolumn{2}{|c|}{ Age } & N & Mean & Std. Deviation & Std. Error Mean \\
\hline \multirow{2}{*}{ Average } & Less than 29 & 53 & 1.9498 & 0.36600 & 0.04375 \\
\cline { 2 - 6 } & More than 29 & 40 & 2.2345 & 0.41199 & 0.08590 \\
\hline
\end{tabular}

It is shown in Table 6 that the mean of the age group less than 29 was (1.94) out of (3), with a standard deviation of $(0.36600)$ and the mean of the age group more than 29 was (2.23) out of (3), with a standard deviation of (0.41199).

As can be noticed, the mean of age group of more than 29 was apparently different and higher than that of the group, which is less than 29. To examine if the means differences between two groups were statistically significant, a t-test for independent samples was calculated, and the results are presented in Table 7. 
Table 7. T-test for independent samples for the differences in perceptions of BL between participants whose age are more than 29 and less than 29 years old

\begin{tabular}{|c|c|c|c|c|c|c|c|c|}
\hline & & \multicolumn{7}{|c|}{ t-test for Equality of Means } \\
\hline & & \multirow[b]{2}{*}{$T$} & \multirow[b]{2}{*}{$D f$} & \multirow[b]{2}{*}{ Sig. (2-tailed) } & \multirow{2}{*}{$\begin{array}{c}\text { Mean } \\
\text { Difference }\end{array}$} & \multirow{2}{*}{$\begin{array}{l}\text { Std. Error } \\
\text { Difference }\end{array}$} & \multicolumn{2}{|c|}{$\begin{array}{c}\text { 95\% Confidence } \\
\text { Interval of the Differ- } \\
\text { ence }\end{array}$} \\
\hline & & & & & & & Lower & Upper \\
\hline \multirow[t]{2}{*}{ Average } & $\begin{array}{l}\text { Equal vari- } \\
\text { ances as- } \\
\text { sumed }\end{array}$ & 3.137 & 91 & 0.002 & -.28474 & 0.09076 & -0.46502 & -0.10445 \\
\hline & $\begin{array}{l}\text { Equal vari- } \\
\text { ances not } \\
\text { assumed }\end{array}$ & 2.954 & 34.157 & 0.006 & -.28474 & 0.09640 & -0.48061 & -0.08886 \\
\hline
\end{tabular}

Table 7 shows that there were statistically significant differences between the more than 29 years old group and less than 29 years old group at $(\alpha=0.05)$, since the (T) value was (3.137) with statistically significant level (002) which is significant at $(\alpha=$ 0.05). This means Syrian refugees who are more than 29 years old are working, and having family, and other commitments, so blended learning is a chance to continue their higher education study without affecting their working or social life.

Question number (5): What are the challenges you face while studying in blended learning system?

In the last part of the online questionnaire, there was an open-ended question about the difficulties and challenges the Syrian refugees faced during their study in a blended learning system. Students' responses were collected, coded, and labeled by the authors independently. Then, the researchers identified the main challenges after comparing, discussing, and resolving conflicts (Cohen et al., 2018).

The findings from the respondents revealed most of them found blended learning useful, positive, and meeting their special needs. However, 89 (95.6\%) stated that they were living in camps, and they did not have access to internet all day, so they sometimes missed the deadline for submitting assignments online because they did not have internet that day. $60(64.5 \%)$ said they did not have laptops or personal computers to do tasks, and participate in the synchronous and asynchronous discussion forums. They just had mobile phones, which were not well equipped to get the benefits of the LMS.

$50(53.7 \%)$ said that they were not confident in using this system especially when taking online exams. Some respondents stated that they faced challenges regarding the difficulty of study and having many assignments: "studying in blended learning is difficult, and I need the help of tutors, but I could not communicate with them as I do not have internet, and buying internet cards is very expensive". Another respondent stated that with the limited abilities of smart phones, "I could not download the course summary and videos in my mobile".

Another respondent said," It is better to cancel assignments which are difficult, and give us exams as in other universities."

Another respondent explained her low performance as she could not cope with the system because she postponed her study and then became shocked when midterm 
exams and the deadline for submitting assignments came near, " This system needs students who are professional in time management, because I have work I do not follow up in the LMS, and I could not cope with all the tasks and the material that I have to study during the exams".

Most respondents said "Getting an official entry permit is the greatest challenge, we have to bring a letter from the university, and go to the security center in the camp to issue the entry permits, this takes at least a week, thereby missing in each month one face to face meeting as we could not go out of the camp."

Many respondents stated that the language of study is a challenge, especially those courses taught in English: " I find studying at Arab Open University is difficult, many courses are in English, and my English level is poor as we do not focus on English language in Syria."

It is clear Syrian refugees had certain challenges that lessened the efficacy of adopting blended learning while providing Syrian refugees with opportunities to study at higher education institutions. However, policymakers in the higher education institutions could manage the challenges and lessen their effects on refugees' study.

\section{Discussion}

This study investigated Syrian refugees' perceptions of the blended learning system used at Arab Open University-Jordan. The research findings revealed that Syrian refugees had positive perceptions of BL. This system met their urgent needs, particularly their financial constraints, thereby giving refugees the chance to work and study at the same time. Female and male refugees also had positive perceptions of this system. That is, they had families, children, and work so this system gave them the opportunities to take care of their families, study, and work simultaneously. The study also revealed the perceptions of refugees of the teaching process, these were to a high degree positive as tutors provided them feedback they needed to study for exams and do their assignments. Tutors also communicated with them via messages and asynchronous discussion forums.

Syrian refugees showed positive perceptions of BL because they perceived the skills that this system taught them, they stated that they became self-learners, and their skills in using computers developed. If they missed any face-to-face lectures, tutors were available to discuss with them the points they found difficult in the course forums, or by uploading videos about the lecture they missed. This implies that Syrian refugees were satisfied with this system as it took into consideration their personal affairs, and the strength of BL is in its flexibility in dealing with higher education studies. This is in line with several previous related studies like [7], [12], [14], [16], [19], [22], [24]. All of these studies revealed that students who experienced BL have positive perceptions of BL as they were satisfied with the convenience, ease of use, and flexibility of learning.

The study results also showed that there were not significant differences between males and females regarding their perceptions of BL. This indicates that gender is not a significant variable in revealing the perceptions of the respondents, and it could be 
inferred that both male and female participants considered BL significant in their tertiary studies. Like this study, [13] found no significant differences in perceptions of the respondents based on their gender. Regarding the effects of age, the current study found that there were significant differences between participants based on their age. That is, participants whose ages were more than 29 were more enthusiastic and had more positive perceptions than those of the participants whose ages were less than 29 . This may be due to the social commitments of the elderly participants like work and family.

Additionally, the current study investigated the challenges that Syrian refugees faced during their experience of studying via BL; to provide policy makers in higher education institutions a comprehensive vision about the success of adopting BL in their institutions, especially for vulnerable groups like refugees.

This study could be the first of its kind according to the knowledge of the authors. It tried to provide instructors, and decision makers in the tertiary education with the necessary data to help them expand BL with refugees and to what extent. It also tried to show how to improve refugees' experiences by taking their challenges into consideration. This study also provides researchers with new vistas to conduct further research in this area, as there are lots of refugees all over the world, and they need support and education to be productive citizens. The results of this study could be a good indicator for international agencies like UNESCO, USAIDS, and UNHCR for their partners in how they employ BL.

\section{Conclusion, Implication, and Limitations of the Study}

This study provided new vistas and insights regarding the Syrian refugees' perceptions of BL in the Middle East as a region of full of crisis with thousands of refugees leaving their countries for other ones searching for a better life and a suitable kind of education. Results therefore reveal that $\mathrm{BL}$ is helping students in the tertiary stage in overcoming their geographical, social, and working constraints. All of the participants were satisfied with their experience of BL at Arab Open University-Jordan particularly with the high level of flexible learning BL approach provided students. Results also indicated that participants valued this system due to the different teaching process and the skills that this approach developed in participants, like self- learning and computer skills compared to the traditional system in the other universities.

In addition to that, the variable of gender did not have any significant differences regarding participants' perceptions, reflecting that this approach is important for both male and female participants and that it meets their demands. This is in line with the previous results that revealed some variables to be of no significance in determining participants' perceptions of BL. Unlike gender, age had a significant difference on determining their perceptions of $\mathrm{BL}$, which is a logical finding as the elderly people have more social and working constraints than those who are younger. This adds a good contribution to the related literature.

It is important to acknowledge that this survey has a limitation as it is a case study in Jordan, and this lessens the generalization of the findings. However, it is noted that 
the findings of this study are generally consistent and supportive of previous literature about BL in other contexts [12], [10], [19].

The findings of the current study also reveal the other side of the truth, the challenges that refugees usually face and that lessen the efficacy of using the BL approach, like lack of internet access, lack of the necessary equipment, and the traditional thinking in students that exams are the best form of evaluation, so they did not like doing assignments that provoked their thinking, and searching skills. This implies the policymakers in tertiary education should think of ways how to deal with these challenges to ensure of the efficacy of employing the BL approach.

All in all, the current study reveals that BL has the potential to assist refugees to overcome their academic challenges and achieve their academic goals and success in higher education; without BL, this could not be achievable.

For researchers and practitioners, further studies should be conducted in other contexts, and to address the effects of each aspect of the BL approach on the perceptions of students, their performance, and thinking skills. Researchers also could investigate the challenges of employing the BL approach from the point of view of instructors to have a comprehensive vision about employing the BL approach effectively.

\section{$8 \quad$ References}

[1] UNESCO, Education for All 2000-2015: Achievements and Challenges. EFA Global Monitoring Report, 2015. Paris, Author. Online. Available: http://unesdoc.unesco.org/images/ 0023/002322/232205e.pdf [Accessed: June.12.2019]

[2] K.D,Watenpaugh, A.L Fricke, and T. Siegel. Uncounted and Unacknowledged: Syria's Refugee University Students and Academics in Jordan. UC Davis Human Rights Initiative and the Institute of International Education: University of California, 2014"

[3] UNHCR, Syria Regional Refugee Response, 2016. Available http://data.unher. org/syrian. [ Accessed June. 8, 2019].

[4] A, Al-Hawamdeh, and H. A, El-Ghali, "higher education and syrian refugee students: the case of Jordan, presented at The Regional Conference On Higher Education In Crisis Situations, Sharm Al-Sheikh- Egypt, 2017.

[5] UNHCR, Innovative Education ApproachConnected/Blended Learning for Refugees, 2019. Available: https://data2.unhcr.org/en/documents/download/69562 [Accessed June. 10,2019]

[6] B, Akkoyunlu, and M.Y, Soylu," A study of student's perceptions in a blended learning environment based on different learning styles", Journal of Educational Technology \& Society, vol.11, no1, pp. 183-193, 2008.

[7] C, Kurt, and I, I,Yildirim, The Students' Perceptions on Blended Learning: AQ Method Analysis. Educational Sciences: Theory and Practice, vol.18, no2, pp. 427-446, 2018 https://doi.org/10.12738/estp.2018.2.0002

[8] B, Güzer, and H, Caner, The past, present and future of blended learning: An in depth analysis of literature. Procedia-Social and Behavioral Sciences, vol. 116, 4596-4603, 2014. https://doi.org/10.1016/j.sbspro.2014.01.992

[9] M. Ja'ashan, Perceptions and Attitudes Towards Blended Learning for English Courses: A Case Study of Students at University of Bisha. English Language Teaching, vol. 8, no.9, pp. 40-50, 2015 https://doi.org/10.5539/elt.v8n9p40 
[10] S. Varthis, S, "Students' Perceptions of Blended Learning and its Effectiveness As a Part of Second Year Dental Curriculum", Ph.D dissertation, Columbia University, Columbia, IL, 2016.

[11] A. Cobanoglu, and B. Yurdakul, The Effect of Blended Learning on Students' Achievement, Perceived Cognitive Flexibility Levels and Self-Regulated Learning Skills, Journal of Education and Practice, vol.5, no22, pp. 176-197, 2014

[12] S.Y. Ju, Perceptions and Practices of Blended Learning in Foreign Language teaching at USIM. European Journal of Social Sciences Education and Research, vol. 12, no1, pp. 170-176, 2018 https://doi.org/10.26417/ejser.v12i1.p170-176

[13] N.Shantakumari, and P. Sajith, A Study of Student's Perceptions of Blended Learning in certificate courses of Gulf Medical University, 2014. Available: http://applications.emro.who.int/imemrf/Gulf_Med_Univ_Proc/Gulf_Med_Univ Proc $2014 \quad 5-6 \quad 183$ 194.pdf [Accessed July.18,2019]

[14] K.B. Al Bataineh, A.A. Banikalef, and A. H. Albashtawi, The Effect of Blended Learning on EFL Students' Grammar Performance and Attitudes: An Investigation of Moodle.Arab World English Journal, vol. 10, no1, pp. 324-334, 2019. Available: https://dx.doi.org/10.24093/awej/vol10no1.27. https://doi.org/10.240 93/awej/vol10no1.27

[15] R. Obiedat, L.N. Eddeen, O, Harfoushi, A.H. Montaha, A. Koury, and N. Alassaf, Effect of blended-learning on academic achievement of students in the University of Jordan. International Journal of Emerging Technologies in Learning (iJET), vol.9, no.2, pp. 37-44, 2014. https://doi.org/10.3991/ijet.v9i2.3220

[16] T. I. Oweis, Effects of Using a Blended Learning Method on Students' Achievement and Motivation to Learn English in Jordan: A Pilot Case Study. Education Research International, 2018. Available: https://doi.org/10.1155/2018/7425924. [ Accessed July. 14,2019]

[17] T. Krasnova, and I. Vanushin, Blended learning perception among undergraduate engineering students. International Journal of Emerging Technologies in Learning (iJET), vol. 11, no.1, pp. 54-56, 2016. https://doi.org/10.3991/ijet.v11i01.4901

[18] D. Adas, and W. Abu Shmais, Students' perceptions towards blended learning environment using the OCC. An-Najah Univ. J. Res.(Humanities), vol. 25, no6, pp.1682-1710, 2011.

[19] R. M. Tamim, Blended learning for learner empowerment: Voices from the Middle East. Journal of Research on Technology in Education, vol. 50, no.1, pp.7083, 2018. https://doi.org/10.1080/15391523.2017.1405757

[20] H. Sharafuddin, and C. Allani, Evaluation of the blended learning system in higher education: AOU-Kuwait. International Journal of Information and Education Technology, vol. 2, no.4, pp. 412-422, 2012 https://doi.org/10.7763/ijiet.2012. v2.166

[21] L. Cohen, L. Manion, and K. Morrison, Research Methods in Education ( $8^{\text {th }}$ ed.). London: Routledge, 2018

[22] Lazem, S. (2019). On Designing Blended Learning Environments for ResourceChallenged Communities. International Journal of Emerging Technologies in Learning, 14(12), 183 - 192 https://doi.org/10.3991/ijet.v14i12.10320

[23] Cacho, R., Avila, R., \& Villaseñor, E. (2017). “What's the Tab's Apps?’: Piloting LowPriced-Tablet-Aided Course Delivery in Teacher Education. International Journal of Emerging Technologies in Learning (IJET), 12(10), 95-111 https:// doi.org/10.3991/ijet.v12i10.7162 
[24] Yu, W., \& Du, X. (2019). Implementation of a Blended Learning Model in Content-Based EFL Curriculum. International Journal of Emerging Technologies in Learning, 14(5), 188 - 199. https://doi.org/10.3991/ijet.v14i05.8546

\section{Authors}

Naima Al-Husban received her Ph.D in Curriculum and Instruction from the University of Jordan in 2016. In 2001 she worked as an EFL teacher for ten years, and she participated with the British Council to train EFL teachers in Jordan and is currently an assistant professor at Arab Open University. She is interested in issues of online teaching, blended learning, literacy instruction, and she has some publications related to teaching English language as a foreign language. She works with Syrian refugees in building their capacities in English language and life skills since 2017.

Sameera Mahmoud Alshorman, Ph.D in science methodology is an assistant professor at Arab Open University - Jordan, she has worked as a teacher for 19 years, and she has awarded Queen Rania Award for excellence in education in 2006.

Article submitted 2019-08-02. Resubmitted 2019-09-22. Final acceptance 2019-09-22. Final version published as submitted by the authors. 